\title{
Production Engineering of the Low Fat Meat Products
}

\author{
M M Danyliv \\ assistant professor of the dept. of Technology of the \\ Products of Animal Origin \\ Voronezh State University of Engineering Technologies \\ Voronezh, Russia \\ e-mail: $\underline{\max -d a n @ y a n d e x . r u}$
}

\author{
O N Ozherelieva \\ assistant professor of the dept. of Biochemistry and \\ Biotechnology \\ Voronezh State University of Engineering Technologies \\ Voronezh, Russia \\ e-mail: ogereleva.1982@mail.ru
}

\author{
O A Vasilenko \\ dept. of Commodity Science and Expertise of Goods \\ Voronezh State Agrarian University named after the \\ Emperor Peter the Great \\ Voronezh, Russia \\ e-mail: ewa007@yandex.ru \\ N M Derkanosova \\ Vice-Rector for Academic Affairs \\ Voronezh State Agrarian University named after the \\ Emperor Peter the Great \\ Voronezh, Russia \\ e-mail: kommerce05@list.ru
}

\begin{abstract}
One of the most significant factors in the prevention of cardiovascular diseases is the nutritional factor. According to the report of the World Health Organization, an unhealthy lifestyle, unhealthy diet, bad habits make up $80 \%$ in the formation of heart diseases. Cooked sausages, produced according to Russian national standards, still take leading place in the diet of Russian citizens, however, most of the sausages produced according to Russian national standards (GOST) contain up to $25 \%$ of fat in their composition, while raw smoked products contain up to $45 \%$ of fat! This paper presents a study of the market of cooked sausages, presented in the range of goods sold by the largest retail chains in the Russian Federation, in particular, the Voronezh region, and the production technology of cooked sausages and sausages with low fat content. One of the solutions is the design of formulations of combined products, which will include various types of vegetable oils along with animal fats. The performed analysis of the experimental data showed that the total mass fraction of omega 3/6/9 unsaturated fatty acids increased in the developed formulations by more than $100 \%$. Our studies with the use computer simulation allow designing the recipes for cooked sausages with a given composition and properties, and the use of vegetable oils in recipes reduces the total fat content by $2-3$ times, while the optimal ratio between proteins, fats and carbohydrates in food is 1:1:4.
\end{abstract}

Keywords - meat products, vegetable oil, animal fat, fatty acid profile, cooked sausage products

\section{INTRODUCTION}

The World Health Organization has adopted the 20152020 Food and Nutrition Action Plan, which is designed to considerably reduce the burden of preventable nutritionrelated noncommunicable diseases, in particular, obesity and any other forms of eating disorders that are still prevalent in the WHO European Region. According to the Global Burden of Disease Survey, in each Member State of the WHO European Region, nutrition is the most important factor undermining the health and well-being of the population $[1,2$, 3]. At present it is recognized that malnutrition, including nutritional deficiencies, micronutrient deficiencies, overweight and obesity, as well as noncommunicable diseases (NCDs) caused by unhealthy diets, lead to significant social and economic losses for people, families, communities and entire nations. Nutrition plays an important role in the prevention of heart diseases. Studies demonstrate that in $80 \%$ of cases, cardiovascular diseases are caused by unhealthy diets and bad habits, and only $20 \%$ of them are caused by other factors. To maintain optimal health, it is necessary to follow both the general rules of a balanced diet and the rules of fat intake. World experience proves that prophylactic work is more effective than the clinical approach to solving these problems $[4,5,6,7]$.

\section{OBJECTS AND METHODS OF THE RESEARCH}

The objects of this research are vegetable oils: olive, corn, rapeseed, soybean, camelina, from various manufacturers in terms of the purpose of their use in recipes of cooked sausages, to replace a part of animal fat with vegetable oil, and to reduce the total fat content in the product. 'Molochnye' and 'Slivochnye' sausages, 'Doktorskaya', 'Molochnaya', and 'Lyubitel'skaya' cooked sausage types are produced in accordance to GOST 56196-2011, 'Govyazhyi' bockwursts are produced in accordance to Product specification (TU) 9213-007-73514497-06. Their fatty acid profile was detected in accordance with the method stated by GOST 30418-96, mass fraction of protein - in accordance with GOST 25011-81, mass fraction of fat - in accordance with GOST 23042-86, moisture - GOST 9793-74, ash - GOST 31727-2012. Starch test was performed in accordance with GOST 10574-91. The most important characteristic of vegetable oils is their fatty acid composition, which we analyzed. Production of fatty acid methyl esters and determination of fatty acid composition was carried out according to standard method of GOST 30418-96 
"Vegetable oils. Fatty acid profile determination method". Fatty acid methyl esters were analyzed using an Agilent $7820 \mathrm{~A}$ gas chromatograph (laboratory of physicochemical analysis methods at Mollab LLC, Voronezh, Russia) with a flame ionization detector and a Supelka capillary column, size $100 \mathrm{~m} \times 0.25 \mathrm{~mm}$. Helium was used as a carrier gas. For the complete separation of fatty acid methyl esters, the separation mode was selected with temperature programming: the column thermostat temperature is programmed from 100 to $185^{\circ} \mathrm{C}$ at a speed of $6-8^{\circ} \mathrm{C} / \mathrm{min}$, then isothermal analysis at $185^{\circ} \mathrm{C}$; evaporator temperature $-250^{\circ} \mathrm{C}$; furnace detectors temperature $-200^{\circ} \mathrm{C}$; the flow rate of the carrier gas (nitrogen, argon, helium) is $30-50 \mathrm{~cm} / \mathrm{min}$, the analysis time is 59 minutes [8].

\section{RESEARCH RESULTS}

The personnel of the department of Technology of the Products of Animal Origin of Voronezh State University of Engineering Technologies together with the personnel of the department of Commodity Science and Expertise of Goods of Voronezh State Agrarian University fulfilled monitoring of the assortment and prices of cooked sausage products in the retail locations of Voronezh and the Voronezh region of the Russian Federation. During this monitoring, the labeling of the products was analyzed, the mass fraction of fat in $100 \mathrm{~g}$ of the product was clarified, and its compliance with the requirements of regulatory documentation was carried out. A sample of retail locations for monitoring is modeled in an amount of at least $15 \%$ of the total, according to their types, purpose, and structure in various areas of the city and region. We selected the retail networks 'Lenta', 'Perekrestok', 'Okey', 'Auchan', 'Magnit'. The research results showed that the main producers of cooked sausage products are following: 'Myasokombinat RegionEkoProdukt', 'Kombinat myasnoy OMPK', Bobrovskiye kolbasy', meat-processing plant 'Familnye kolbasy', meat-processing plants 'Atyashevskiy', 'Cherkizovo', 'Velkom', 'Velikolukskiy', 'Sochinskiy', 'Dymovskiy', 'Meat House', 'Chernyshevoy', etc. In total, 32 types of sausages were tested including 12 produced in accordance with GOST R 52196-2011, 1 - GOST 31498-2012, and 19 in accordance with TU. The comparative analysis of the mass fraction of fat stated on the label demonstrated that it was below $34 \%$ in 1 sample, below $25-30 \%$ in 16 samples, below $20-25 \%$ in 8 samples, below $15-20 \%$ in 5 , below $10-$ $15 \%$ in 2 samples. Among the 67 types of cooked sausages 19 were produced in accordance with GOST R 52196-2011, 1 - in accordance with GOST R 53645-2009, 45 types were produced in accordance with TU, and 2 types - in accordance with industry standards (STO). Analysis of the cooked sausages produced in accordance with TU and STO showed that only three samples had the mass fraction of fat below 11, 15,5 , and $18 \%$ correspondingly. In 7 samples the mass fraction of fat varies from 30 to $40 \%$.

Thus, in the ration of Voronezh residents, the share of cooked sausage products with guaranteed high fat content is $37.5 \%$ for sausages and $29.9 \%$ for cooked sausages, therefore, $98 \%$ of cooked sausage products sold in the retail networks of Voronezh and the region contain more than $20 \%$ fat.
To verify that the nutritional values of the test samples comply with the requirements of the regulatory documentation, their chemical composition was analyzed. In each of the selected samples, the protein content was determined by the Kjeldahl sample mineralization method and photometric measurement of indophenol blue color; the fat content - using the Soxhlet extraction apparatus, the mineral substances (ash) content - after the sample was ashed at the temperature of $(550 \pm 25)^{\circ} \mathrm{C}$, the moisture content - through drying in a drying cabinet at a temperature of $(150 \pm 2)^{\circ} \mathrm{C}$, starch content - by oxidation of aldehyde groups of monosaccharides formed during hydrolysis of starch in an acidic environment with divalent copper and reduction of copper oxide to protoxide and subsequent iodometric titration. The analysis results are demonstrated in the Tables 1, 2 below.

TABLE I. COMPARATIVE ANALYSIS OF THE CHEMISTRY OF SAUSAGES

\begin{tabular}{|c|c|c|c|c|c|c|}
\hline \multirow[b]{2}{*}{ Indicator } & \multicolumn{2}{|c|}{$\begin{array}{c}\text { 'Molochnye' } \\
\text { sausages }\end{array}$} & \multicolumn{2}{|c|}{$\begin{array}{c}\text { 'Slivochnye' } \\
\text { sausages }\end{array}$} & \multicolumn{2}{|c|}{$\begin{array}{l}\text { 'Govyazhyi' } \\
\text { bockwursts }\end{array}$} \\
\hline & 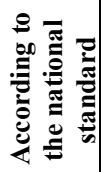 & 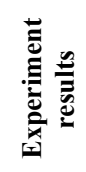 & 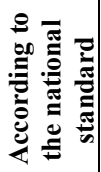 & 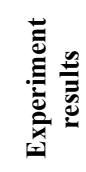 & 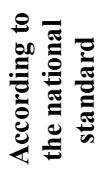 & 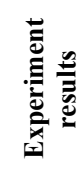 \\
\hline Protein, \% & 11.00 & 13.92 & 10.00 & 13.20 & 9.00 & 12.20 \\
\hline Fat, $\%$ & 28.00 & 24.20 & 19.00 & 20.90 & 18.00 & 17.90 \\
\hline Moisture, $\%$ & 58.30 & 59.36 & 68.30 & 63.40 & 70.20 & 67.10 \\
\hline Ash, $\%$ & 2.70 & 2.52 & 2.70 & 2.50 & 2.80 & 2.80 \\
\hline Starch test, \% & \multicolumn{6}{|c|}{ Not found } \\
\hline
\end{tabular}

TABLE II. COMPARATIVE ANALYSIS OF THE CHEMISTRY OF COOKED SAUSAGES

\begin{tabular}{|c|c|c|c|c|c|c|}
\hline \multirow[b]{2}{*}{ Indicator } & \multicolumn{2}{|c|}{$\begin{array}{l}\text { 'Doktorskaya' } \\
\text { cooked sausage }\end{array}$} & \multicolumn{2}{|c|}{$\begin{array}{l}\text { 'Molochnaya' } \\
\text { cooked sausage }\end{array}$} & \multicolumn{2}{|c|}{$\begin{array}{l}\text { 'Lyubitel'skaya' } \\
\text { cooked sausage }\end{array}$} \\
\hline & 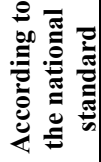 & 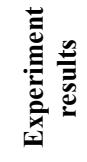 & 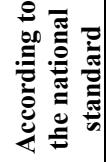 & 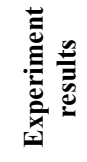 & 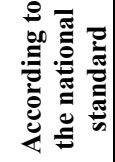 & 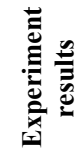 \\
\hline Protein, \% & 12.00 & 11.50 & 11.00 & 10.85 & 12.00 & 10.60 \\
\hline Fat, \% & 20.00 & 19.50 & 22.00 & 22.85 & 28.00 & 29.03 \\
\hline Moisture, \% & 65.30 & 66.40 & 64.3 & 63.52 & 57.2 & 57.33 \\
\hline Ash, $\%$ & 2.70 & 2.52 & 2.70 & 2.66 & 2.80 & 2.68 \\
\hline Starch test, $\%$ & & & & & & \\
\hline
\end{tabular}

The data obtained during the experimental studies were compared with those indicated on the label in order to identify deviations, as well as possible violations and falsifications. It can be seen from the presented values that there is the deviation in the mass fraction of fat in sausages 'Slivochnye', no deviation is detected in the mass fraction of protein, mineral substances and moisture, starch is also not detected in the samples. The use of vegetable oil in sausage recipes aimed at reduction of animal fat content by replacing part of the main and auxiliary raw materials. The quality characteristic of the fat is its fatty acid profile, which was analysed with the use of 


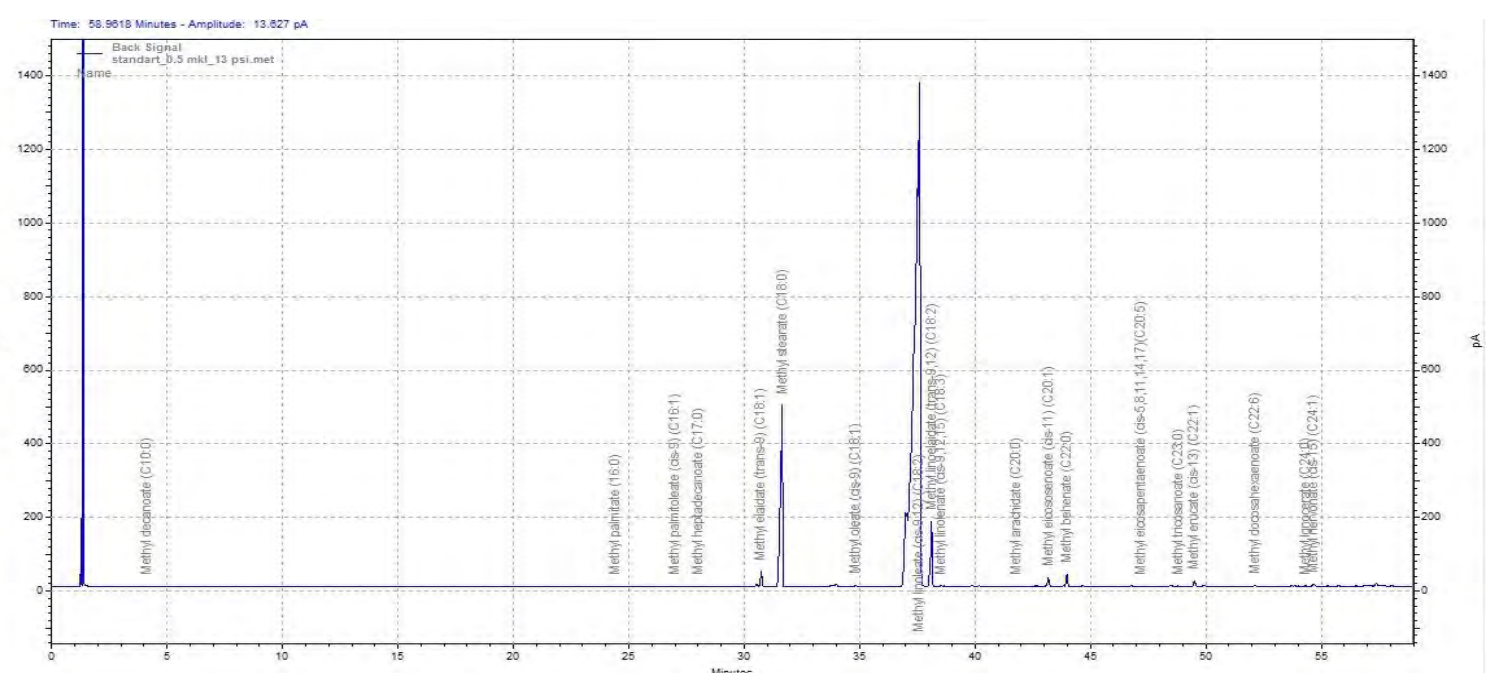

Fig. 1. Olive oil chromatogramme

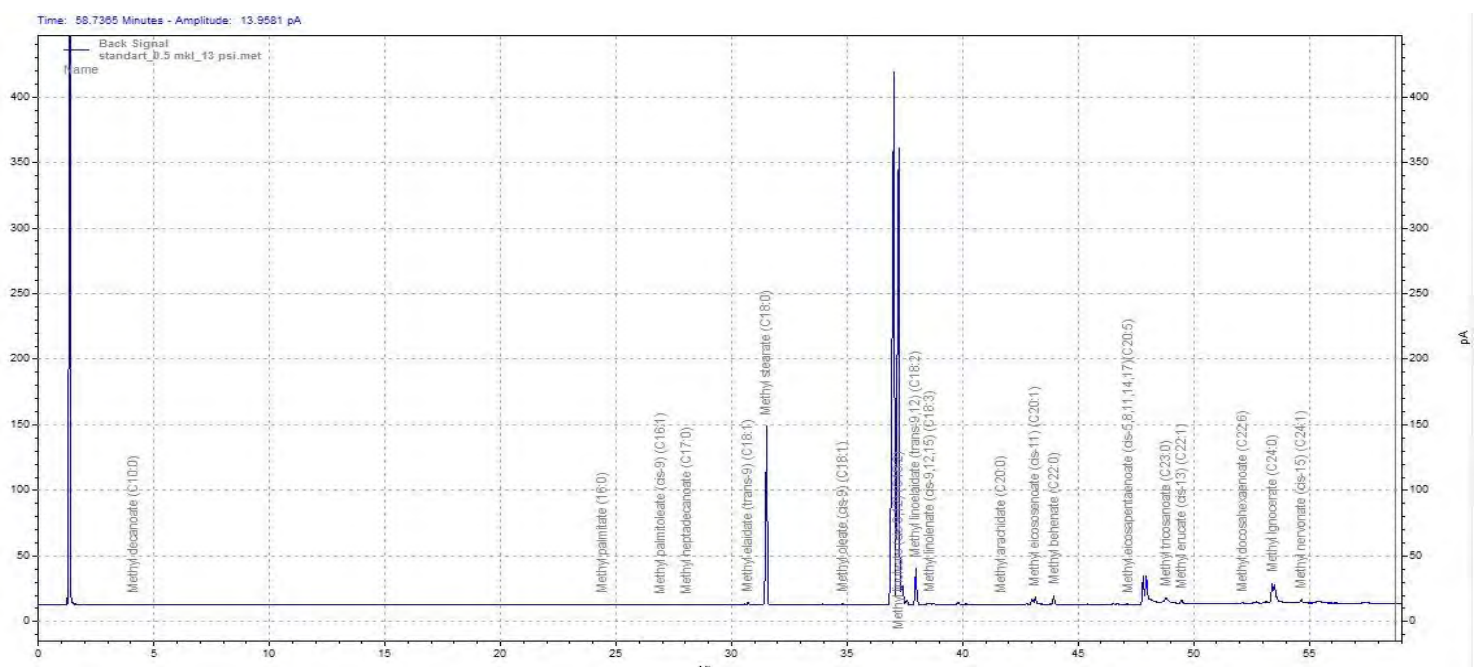

Fig. 2. Camelina oil chromatogramme

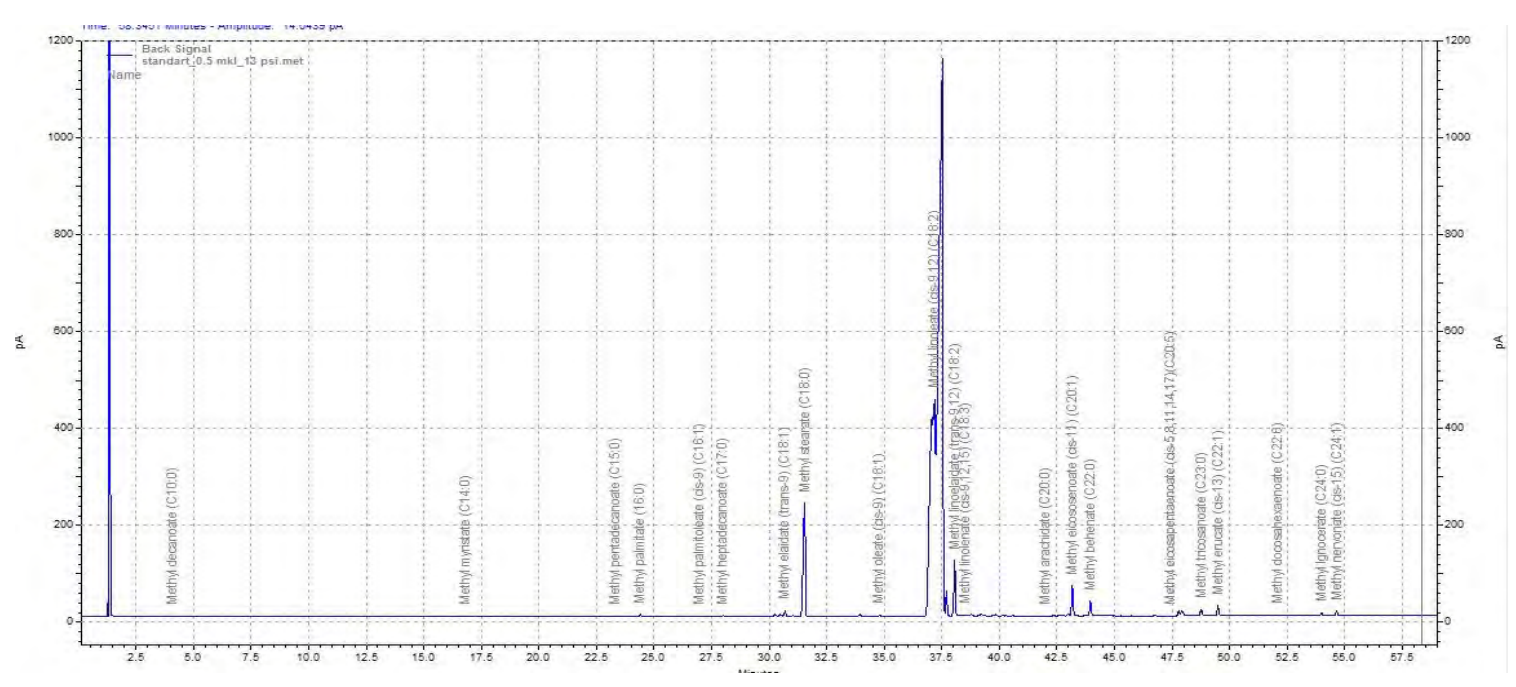

Fig. 3. Rapeseed oil chromatogramme 
Agilent 7820A gas chromatograph (laboratory of physicochemical analysis methods at Mollab LLC, Voronezh, Russia) according to the regulatory documentation and manufacturer's recommendations. We used the standard set of fatty acids Supelco ${ }^{\circledR} 37$ Component FAME Mix $10 \mathrm{mg} / \mathrm{mL}$ in methylene chloride (varied), analytical standard manufactured by «Sighma Aldrich» [8]. The examples of the chromatogrammes of the vegetable oils are shown in Figures $1-3$, the values of the mass fractions of the fatty acids are presented in Table 3.

TABLE III. FATTY ACID COMPOSITION OF THE VEGETABLE OILS

\begin{tabular}{|c|c|c|c|c|c|c|}
\hline \multirow[b]{2}{*}{$\begin{array}{c}\text { Fatty acid } \\
\text { identificatio } \\
\text { n code }\end{array}$} & \multirow[b]{2}{*}{ Fatty acid } & \multicolumn{5}{|c|}{$\begin{array}{l}\text { Mass fraction of the fatty acids in } \\
\text { the oil (mass \%) }\end{array}$} \\
\hline & & $\begin{array}{l}\overline{0} \\
0 \\
.0 \\
0\end{array}$ & 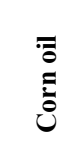 & 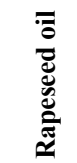 & 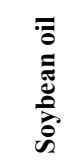 & 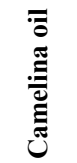 \\
\hline C16:0 & Palmic & 2.60 & 10.40 & 5.00 & 3.00 & 10.40 \\
\hline C18:0 & Stearinic & 5.25 & 2.10 & 2.11 & 3.45 & 2.10 \\
\hline C18:1 & Oleinic & 64.9 & 24.85 & 48.36 & 19.45 & 24.85 \\
\hline C18:2 & Linoleic & 21.60 & 54.66 & 32.01 & 62.85 & 54.66 \\
\hline C18:3 & Linolenoic & 2.30 & 2.30 & 5.22 & 7.80 & 2.30 \\
\hline C20:1 & Eicosenoic & 0.39 & 1.84 & 3.37 & 0.89 & 1.84 \\
\hline $\mathrm{C} 22: 0$ & Behenic & 0.53 & 1.05 & 1.44 & 1.20 & 1.05 \\
\hline C22:1 & Erucidic & - & 0.3 & 1.06 & 1.00 & 0.3 \\
\hline $\mathrm{C} 23: 0$ & Tricosanic acid & - & 2.20 & 0.86 & - & 2.20 \\
\hline
\end{tabular}

The experimental data obtained confirm that vegetable oils are rich in unsaturated fatty acids. The study results presented in the Figures and the Table showed that the largest mass fraction of oleinic acid was detected in olive and rapeseed oils - 64 and $48 \%$ correspondingly, the largest mass fraction of linoleic acid is in corn and soybean oils - 54 и $62 \%$, linolenoic acid - in soybean and rapeseed oils -7.8 and $5.2 \%$ correspondingly $[9,10]$. The further task of the work was design of a product with reduced fat content; for its modeling the recipes of cooked sausages, the most popular on the market, were selected $[11,12,13]$. The main components of the new formulations were: beef and pork with minimum content of connective tissue, rabbit meat, iodized sea salt, vegetable oils, and other auxiliary ingredients $[14,15]$. To create the recipe-component solutions, the system of computer modeling of recipe-component solutions "Generic 2.0" was used. The fat mass fraction was chosen as an optimization criterion to be set at a certain level: for 'Greek' sausages $10 \%$, Slivochnye-light' sausages - 12\%, 'Beef-dietic' sausages - $12 \%$, for 'Doktorskaya' cooked sausage - 7\%, 'Molochnayatender' cooked sausage - 10\%, and 'Lyubitelskaya-dietic' $13 \%$. Examples of the formulations of the designed products, as well as the software interface are presented in Figure 4.
TABLE IV. THE STUDY RESULTS FOR THE CHEMISTRY OF SAUSAGES

\begin{tabular}{|c|c|c|c|c|c|c|}
\hline Indicator & 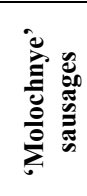 & 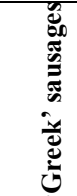 & 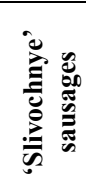 & 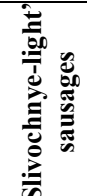 & 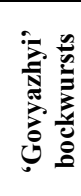 & 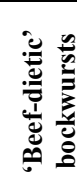 \\
\hline Protein, $\%$ & 13.92 & 15.78 & 13.20 & 14.22 & 12.20 & 16.30 \\
\hline Fat, $\%$ & 24.20 & 10.25 & 20.90 & 12.31 & 17.90 & 11.95 \\
\hline Moisture, $\%$ & 59.36 & 71.06 & 63.40 & 70.69 & 67.10 & 68.82 \\
\hline Ash, \% & 2.52 & 2.91 & 2.50 & 2.78 & 2.80 & 2.93 \\
\hline
\end{tabular}

Based on the results of the simulation, an experimental lots of 'Greek', 'Slivochnye-light' and 'Beef-dietic' bockwursts were produced. The technological process of production was carried out according to the traditional technological scheme, where at the stage of meat preparation in the cutter vegetable oils were added according to the ratio found from the simulation [16]. The studies of the chemical composition of the designed sausages are presented below. The obtained results are summarized in Tables 4,5 .
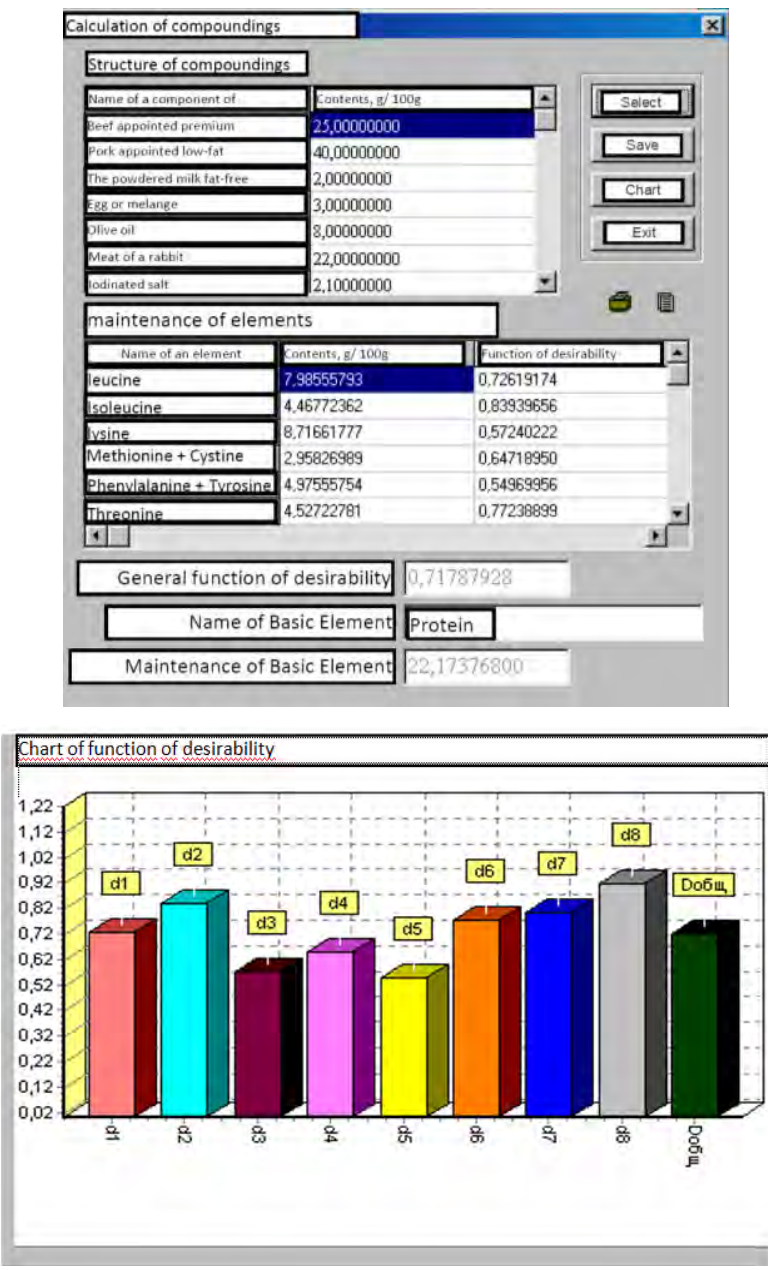

Fig. 4. Calculation of the recipe for 'Greek' sausages and the desirability function

TABLE V. THE STUDY RESULTS FOR THE CHEMISTRY OF COOKES SAUSAGES 


\begin{tabular}{|c|c|c|c|c|c|c|}
\hline Indicator & 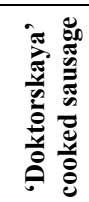 & 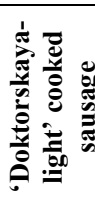 & 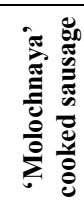 & 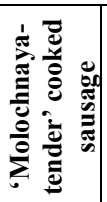 & 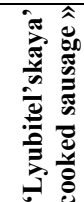 & 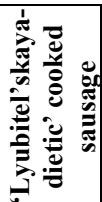 \\
\hline Protein, \% & 12.00 & 16.7 & 11.00 & 14.10 & 12.00 & 14.20 \\
\hline Fat, $\%$ & 20.00 & 6.9 & 22.00 & 10.20 & 28.00 & 13.10 \\
\hline Moisture, \% & 65.30 & 73.2 & 64.30 & 73.10 & 57.2 & 69.90 \\
\hline Ash, \% & 2.70 & 3.2 & 2.70 & 2.60 & 2.80 & 2.80 \\
\hline
\end{tabular}

The experimental data show that the tested sample of 'Greek' sausages the mass fraction of protein was $1.86 \%$ higher and the mass fraction of fat $-13.25 \%$ lower than in similar marketed type, in 'Slivochnye-light' sausages - 1.02 and 8.59 $\%$, in 'Beef-dietic' bockwursts -4.1 and $5.95 \%$ correspondingly, which argues the improvement of biological value of 'Greek' sausages due to reduction of fat mass fraction and increase of protein mass fraction. In the designed samples of cooked sausages, the mass fraction of protein was increased by almost 1.5 times, the mass fraction of fat was reduced by more than 2 times.
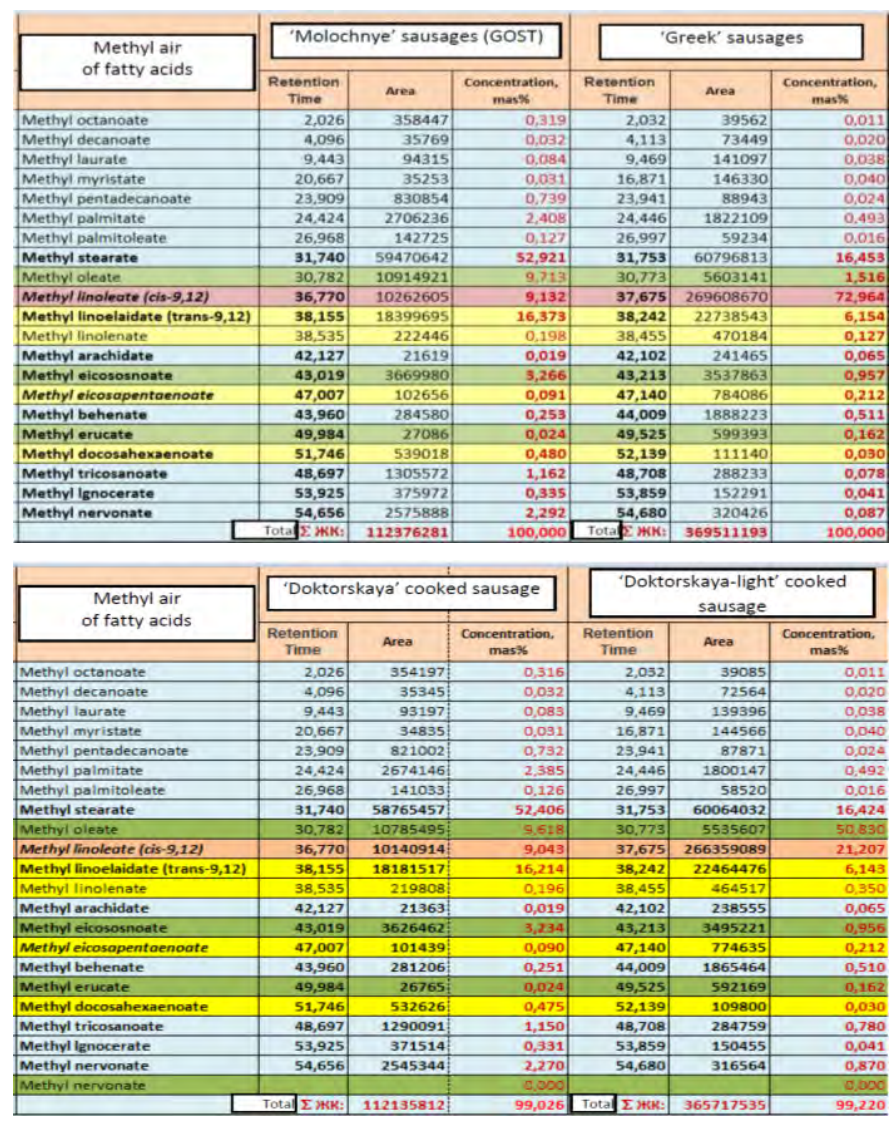

Fig. 5. Comparative analysis of fatty acid composition of cooked sausage products

The obtained indicators allow us to talk about improving the nutritional value of the designed product, which meets modern requirements of food hygiene. Such ratio of basic nutrients meets the current principles of healthy nutrition. It is also worth noting that the main part of fats in this product is of plant origin, in contrast to the products manufactured according to the classical regulatory documentation, where mostly animal fats prevail. The presence of vegetable fats makes the meat product enriched in unsaturated fatty acids, which also indicates an improvement in its nutritional value, due to the presence of essential fatty acids [17]. Further, it was of interest to study the change in the qualitative composition of fat in sausages newly designed and those sold in the retail networks, for which we carried out a comparative analysis of the fatty acid composition of the fat extracted by the extraction method from 'Molochnye' sausages, 'Doktorskaya' cooked sausage, designed 'Greek' sausages and 'Doktorskaya-light' cooked sausage. The results of the experimental tests of fatty acid composition of the fat from the manufactured samples are shown in Figure 5.

Graphical interpretation of the data is presented in Figures. 7-9 below.

Based on the results of experimental studies of the fat of 'Molochnye' sausages, large mass fraction of saturated stearic fatty acid was found - $52 \%$ by weight, linolenoic fatty acid $16 \%$ by weight, oleic and linoleic acids by $9 \%$ by weight, which indicates the predominance of saturated fatty acids. The obtained results allow us to conclude that in 'Greek' sausages the qualitative composition of fat has changed, the content of saturated stearic acid is reduced by $68.5 \%$ by weight, palmic by $80 \%$ by weight, and the content of unsaturated fatty acids is increased: oleic acid - by $81 \%$ weight \%, linoleic - by 7.8 wt.\%. Similar situation can be traced in the case of 'Doktorskaya' and 'Doktorskaya-light' cooked sausages. The Omega 3-6-9 complex contained in 'Greek' sausages has increased by $109.1 \%$, and in 'Doktorskaya-light' cooked sausage - by $105.5 \%$ compared to the cooked sausages produced according to classical regulatory documentation. Our studies with the use computer simulation allow designing the recipes for cooked sausages with a given composition and properties, and the use of vegetable oils in recipes reduces the total fat content by 2-3 times, while the optimal ratio between proteins, fats and carbohydrates in food is 1:1:4 $[9,10]$.

\section{SUMMARY}

Properly chosen diet plays a significant role in human life, because it is nutrition that gives a person energy, strength, and the right approach to it gives health. Food products are the main source of the body's basic nutrients - essential amino acids, unsaturated fatty acids, macro- and micronutrients, vitamins. Currently, cooked sausages in the Russian market contain mainly animal fats, where the mass fraction of saturated fatty acids and cholesterol is quite high. These fats are difficult to digest, poorly oxidized, and the action of the enzymes of the digestive tract is slow. Replacing animal fats with vegetable oils is included in the healthy nutrition programme not only in Russia, but also in the EU countries, which is associated with high content of unsaturated fatty acids in them, that contribute to faster removal of cholesterol from the body, at the same time, these fats are easily digested and assimilated. 


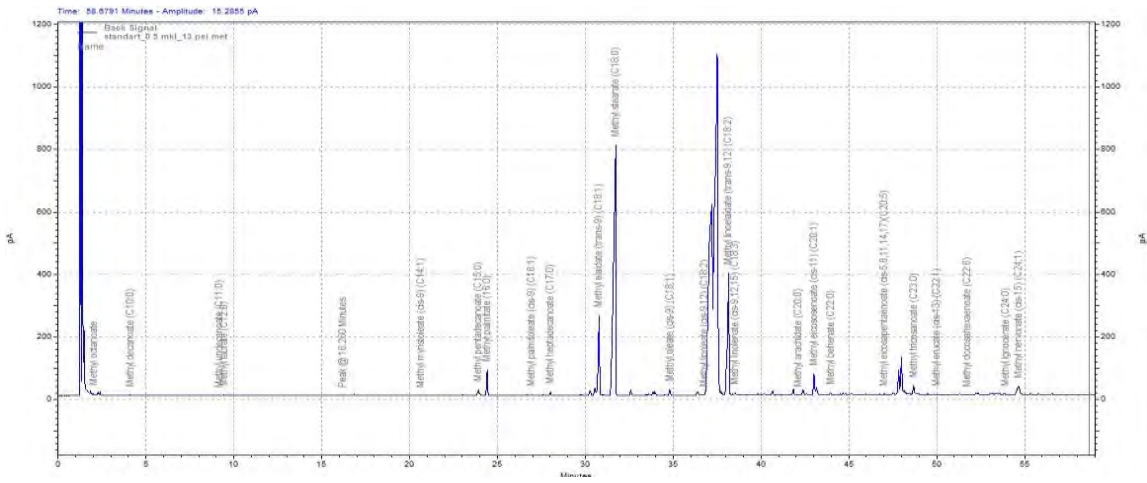

Fig. 6. Chromatogramme of the fat extracted from 'Molochnye' sausages

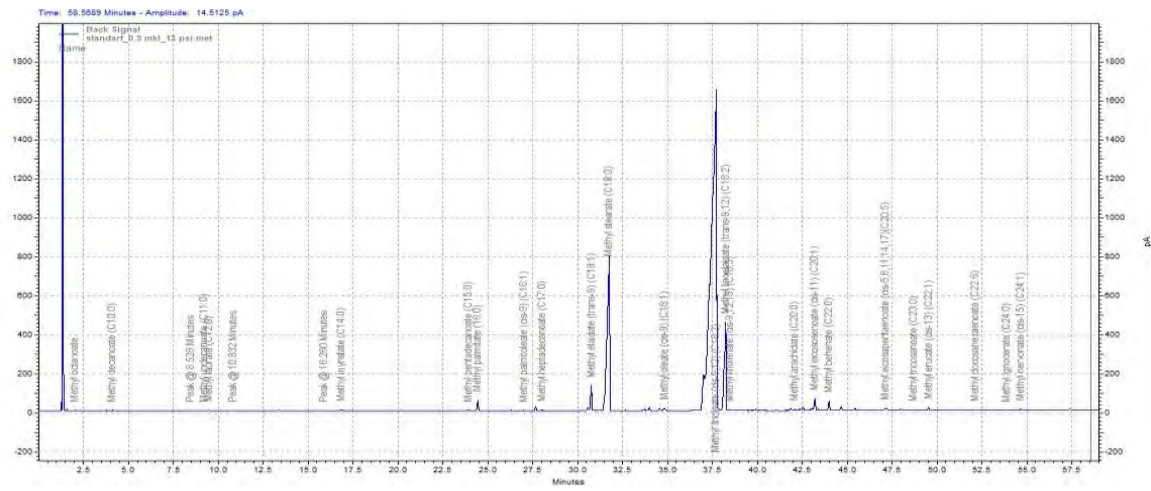

Fig. 7. Chromatogramme of the fat extracted from 'Greek' sausages

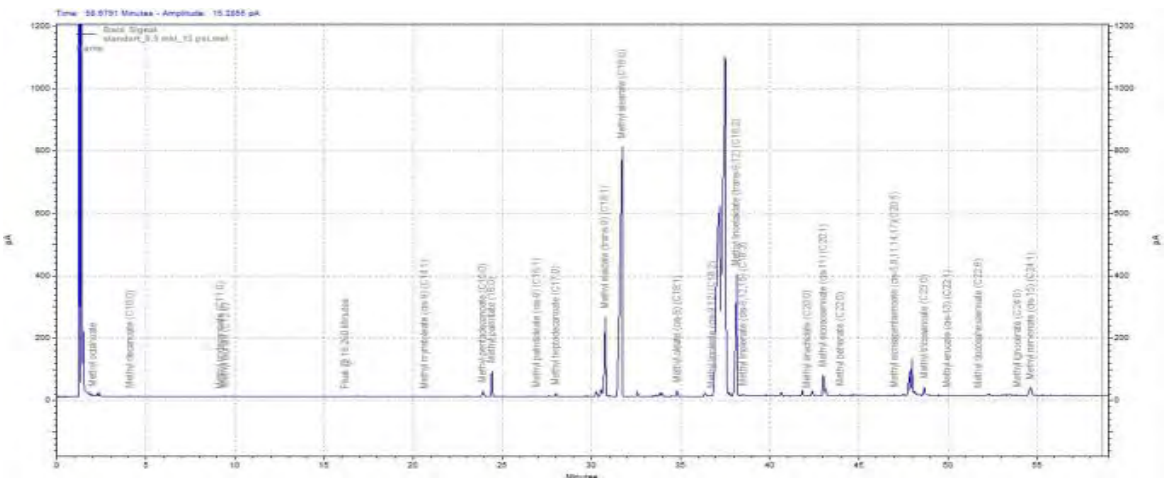

Fig. 8. Chromatogramme of the fat extracted from 'Doktorskaya' cooked sausage

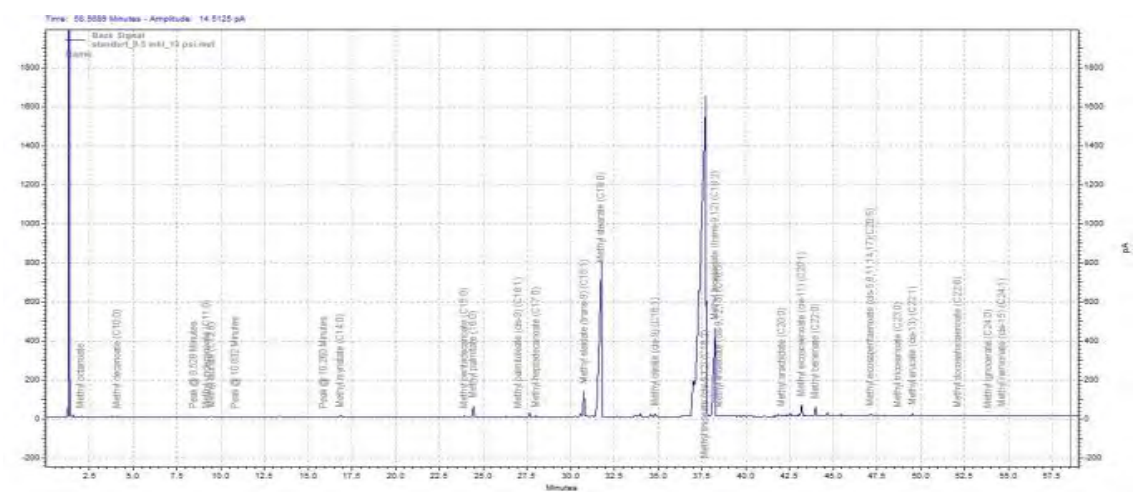

Fig. 9. Chromatogramme of the fat extracted from 'Doktorskaya-light' cooked sausage 


\section{References}

[1] Cardiovascular diseases - Retrieved from: http://www .who.int/mediacentre/factsheets/fs317/ru/. - World Health Organization. - (Date of the address: 9.03.2015)

[2] Peterson E. B., Van Eenoo E. JR, Mcguirk A, Preckel P.V. "Perceptions of fat content in meat products“, Agribusiness, 2001, №4

[3] Michaud D.S., Giovannucci E, Willett W.C., Colditz G.A., Fuchs C.S . "Dietary meat, dairy products, fat, and cholesterol and pancreatic cancer risk in a prospective study ", American Journal Of Epidemiology, Oxford University Press, 2003, № 12

[4] Kalliopi M.,Petros M.,Ladislav M.,Anne-Katrin B., Jan W.,Sandra C.,Franz U., «Viewpoint: Future of food safety and nutrition Seeking win-wins, coping with trade-offs», Food Policy, Volume 74, 2018, pp. 143-146

[5] Mark McC.,Elodie C.,Kerstin D.,Rachel N., "Food and health research in Europe: Structures, gaps and futures", Food Policy, Volume 39, 2013, Pages 64-71

[6] Stewart-Knox B.J., Markovina J., Rankin A., Bunting B.P., Kuznesof S., Fischer A.R.H., I.A. van der Lans, Poínhos R., M.D.V. de Almeida, L. Panzone, Gibney M., Frewer L.J. «Making personalised nutrition the easy choice: Creating policies to break down the barriers and reap the benefits», Food Policy, vol. 63, 2016, pp. 134-144

[7] Polyanskikh S.V., Ilyina B.M., Grebenshchikov A.V., Klyuchnikova D.V., Dolmatova O.I., Bogdanova E.V., " Products of Animal Origin with Vegetable Components", Indian Journal of Science and Technology, vol 9(39), DOI: 10.17485/ijst/2016/v9i39/103431, October 2016

[8] GOST 30418-96. Oils vegetable. Method of definition of zhirnokislotny structure, Moscow: IPK Standards Publishing House, 2001, p. 12

[9] Danyliv M.M., Vasilenko O.A., Plutalova M.V., Bogdanova E.V. 'Design of the sausage recipes with reduced fat concentration based on the analysis of the conditions within the meat product market of Voronezh', Voronezh State agrarina university bulletin, 2016, vol. 3 (50), pp. 183-195
[10] Danyliv M.M., Korolev I.S., Plutalova M.V., Vasilenko O.A., "The technology of meat semi-products with reduced fat concentration", Technologies in food and pharmaceutical processing industries of the agro-industrial complex - healthy foods, 2016, vol. 9, No. 1, pp. $35-$ 42.

[11] S.Y. Hsu, S.H. Yu, «Comparisons on 11 plant oil fat substitutes for low-fat Kung-wans», Journal of Food Engineering, Volume 51, No. 3, 2002, pp. 215-220

[12] S.Y. Hsu, S.H. Yu, «Cooking effects on low-fat Kung-wans formulated with plant oils», Journal of Food Engineering, Volume 56, No. 4, 2003, pp. 299-305

[13] Hasan M.V., «Low-fat beef patties with cold-pressed oils optimized by mixture design», Journal of Food and Nutrition Research, Vol. 55, 2016, No. 1, pp. 89-100

[14] Yu, S.-S \& Hsu, S.-Y. The effect of coconut oil, soybean oil, salt and phosphates on the quality of simmered lower-fat kung-wans. Taiwanese Journal of Agricultural Chemistry and Food Science, 2008, vol. 46, pp. 234-242.

[15] Yu, S.-S \& Hsu, S.-Y. Effects of coconut oil, soybean oil, salt and phosphates on qualities of low-fat emulsified meatballs. Taiwanese Journal of Agricultural Chemistry and Food Science, 2007, vol. 45. pp. 300-309.

[16] Choi, Yun-Sang \& Choi, Ji-Hun \& Han, Doo-Jeong \& Kim, HackYoun \& Lee, Mi-Ai \& Jeong, Jong Youn \& Chung, Hai-Jung \& Kim, Cheon-Jei. (2010). Effects of replacing pork fat with vegetable oils and rice bran fiber on the quality of reduced-fat frankfurters. Meat science. vol. 84, pp. 557-63. 10.1016/j.meatsci.2009.10.012.

[17] Bolger Z. et al., Impact of inclusion of flaxseed oil (pre-emulsified or encapsulated) on the physical characteristics of chicken sausages / Journal of Food Engineering, vol. 230, 2018,pp. 39-48 